\title{
Assessment of Host-Induced Selection on Three Geographic Isolates of Heterodera schachtii Using RAPD and AFLP Markers
}

\author{
M. Kaplan, E. P. Caswell-Chen, and V. M. Williamson
}

First author: Departments of Plant Pathology and Nematology, University of California, Davis 95616; and second and third authors: Department of Nematology, University of California, Davis. Accepted for publication 28 September 1998.

\begin{abstract}
Kaplan, M., Caswell-Chen, E. P., and Williamson, V. M. 1999. Assessment of host-induced selection on three geographic isolates of Heterodera schachtii using RAPD and AFLP markers. Phytopathology 89:68-73.

The hypothesis that host plants exert selection pressure on Heterodera schachtii populations was tested. Host selection of genotypes from three genetically distinct isolates of $H$. schachtii was assessed using cabbage, sugar beet, oilseed radish (Raphanus sativus), and white mustard (Sinapis $a l b a$ ). The plants represent a range of susceptibility to $H$. schachtii and included $R$. sativus and $S$. alba, because cultivars of those species have been used as trap crops for $H$. schachtii in Europe. Genotypic differences in amplified fragment length polymorphism (AFLP) and random ampli-

RAPD markers. Oilseed radish selected nematode genotypes in less than four nematode generations. The nematode population genotypes detected by RAPD analyses after selection on oilseed radish were observed even after nematode populations were transferred back to the other three hosts. The genetic markers that were detected after selection were influenced by the genotypes of the original nematode isolates. The results indicate the utility of RAPDs and AFLPs for identifying and monitoring intraspecific genetic variability in nematodes and for understanding nematode population responses to host plants. Nematode management practices such as using resistant cultivars may alter gene frequencies, thereby reducing the efficacy of the tactic and exacerbating the nematode's potential to damage subsequent crops.
\end{abstract} fied polymorphic DNA (RAPD) markers were detected among the isolates after they reproduced on the different hosts. The poorest host plant, $R$. sativus, resulted in the greatest number of changes in both AFLP and
Additional keywords: Beta vulgaris, Brassica oleracea, cyst nematode, PCR, population genetics.
Heterodera schachtii Schmidt, the sugar beet cyst nematode (SBCN), causes severe yield losses of sugar beet worldwide (12). The SBCN has a wide host range that includes members of 23 plant families and has been reported to cause economic damage on cole crops in California (13). Crop-mediated management tools such as crop rotation, resistant varieties, cover crops, and trap crops are tactics for reducing nematode numbers in soil $(1,8,18)$. The effective use of these methods requires an understanding of the degree to which hosts exert selection pressure on nematode populations. Anticipating host-induced selection is particularly important with respect to assessing the durability of resistant cultivars.

Significant genetic variability has been recognized within species in the genus Heterodera. Directional selection induced by resistance genes in soybean, barley, and sugar beet has resulted in the recognition of pathotypes in $H$. glycines, $H$. avenae, and $H$. schachtii $(14,16)$. As new sources of resistance are deployed, new pathotypes are selected $(10,11)$. Genetic variability exists among geographic isolates of $H$. schachtii and is exhibited by host-range variation, differences in ability to penetrate seedlings and to damage hosts, and differences in the rapidity of population increase $(9,14)$. The genetic diversity in nematode populations is an important consideration in choosing nematode management tactics $(2,9,14)$. There is a need for increased understanding of how hosts affect the genetic structure of nematode populations, especially with respect to nematode fitness and the success of crop-mediated nematode management.

Developments in DNA technology provide tools for identifying potentially useful markers to aid in understanding host-pathogen

Corresponding author: E. P. Caswell-Chen; E-mail address: epcaswell@ucdavis.edu

Publication no. P-1998-1123-03R

(c) 1999 The American Phytopathological Society interactions and the long-term effects of those interactions on pathogen populations. A DNA polymorphism assay based on random amplified polymorphic DNA (RAPD) using polymerase chain reaction (PCR) has been found useful for discriminating isolates of the same species $(21,22)$, although some RAPD bands may be difficult to reproducibly amplify (6). Caswell-Chen et al. (5) used RAPD markers to differentiate among six geographic populations of $H$. schachtii. Another powerful technique, which uses selective amplification of DNA restriction fragments to generate amplified fragment length polymorphisms (AFLPs), is a more specific, reproducible, and efficient PCR-based method to identify DNA markers (20). The more stringent amplification conditions used to produce AFLPs allow markers to be reproducibly generated $(2,7)$, and thus, AFLPs are more reliable for molecular markers than are RAPDs. Folkertsma et al. (7) successfully used AFLP to distinguish species and populations of cyst nematodes in the genus Globodera.

The goals of the current research were to use DNA markers to test the hypothesis that host plants exert selection on $H$. schachtii populations and to identify DNA markers associated with the capacity to parasitize particular plants. The ability of each of four hosts to select for specific genotypes among each of three $H$. schachtii isolates was investigated. The nematode isolates were chosen because they were known to be genetically distinct as demonstrated by RAPD markers (5) and because of the geographic diversity of their origin. The host plants were chosen as representing a range of susceptibility to $H$. schachtii and specifically included Raphanus sativus and Sinapis alba because cultivars of those species have been used successfully in Europe as trap crops to reduce $H$. schachtii numbers in soil (8). Two PCR-based marker techniques, RAPD and AFLP, were used to assess genetic differences among the three $H$. schachtii geographic isolates after they reproduced on each host and after they were transferred from one host to another. 


\section{MATERIALS AND METHODS}

Nematodes and plants. Three genetically distinct California isolates of $H$. schachtii, one originating from Half Moon Bay (HMB) and two from the Imperial Valley (Palm B2 and Palmetto), were collected in 1991 and cultured on cabbage (Brassica oleracea cv. Copenhagen Market) in the greenhouse (5). Within the desert environment of southern California, the original Palm B2 and Palmetto fields are separated by approximately $4.8 \mathrm{~km}$ in an interconnected irrigation system. The HMB location is a coastal, rainfed and sprinkler-irrigated field located approximately $800 \mathrm{~km}$ northwest of the Imperial Valley fields.

Four plant species of differing host quality were used: a poor host, oilseed radish ( $R$. sativa cv. Siletta Nova); a moderately good host, white mustard ( $S$. alba cv. Albatross); and two good hosts, cabbage (Brassica oleracea cv. Copenhagen Market) and sugar beet (Beta vulgaris).

Nematode cultures. Each of the three nematode isolates were reared on each of the four plants, resulting in the production of 12 $H$. schachtii populations. After a nematode isolate was reared on one of the four plants, it is herein referred to as a population. We call this the first-host sequence. Seeds of the four host plants were planted in $15-\mathrm{cm}$-diameter clay pots filled with river sand, after which the pots were placed on greenhouse benches and maintained at approximately 22 to $28^{\circ} \mathrm{C}$. Cysts of each isolate were collected from cabbage plants on a 150 - $\mu \mathrm{m}$-pore sieve (4), and 400 to 600 cysts were used to inoculate 2 -week-old seedlings of each of the four hosts. At 80 days after inoculation (approximately four $H$. schachtii generations [17]), roots from five replicates of each plantnematode combination were rinsed clean of sand and $H$. schachtii cysts were collected on a $150-\mu \mathrm{m}$-pore sieve (4). Two or three replicates of 50 cysts from 9 of the 12 populations arising from the firsthost sequence were placed in microcentrifuge tubes, quick-frozen in liquid nitrogen, and stored at $-80^{\circ} \mathrm{C}$. Collecting sufficient quantities of cysts was a problem; therefore, the only Palmetto population from which cysts were collected and frozen was Palmetto reared on cabbage. The remaining cysts from the 12 populations were placed on Baermann funnels and second-stage juveniles (J2) were collected (19). To insure that all the nematodes collected were the same stage, the nematodes collected during the first $24 \mathrm{~h}$ were discarded.

More J2 from all 12 first-host sequence populations were collected during days 4 through 8 for DNA analyses. Two replicates of approximately $2,000 \mathrm{~J} 2$ were put into $1.5-\mathrm{ml}$ microfuge tubes, centrifuged for $15 \mathrm{~min}$ at $11,750 \times g$, and the excess water discarded. A total of $600 \mu \mathrm{l}$ of $70 \%$ sucrose was added to the J2, thoroughly mixed, and then overlaid with sterile deionized water and centrifuged at $735 \times g$ for $5 \mathrm{~min}$. The floating $\mathrm{J} 2$ were transferred to a new tube and rinsed three times with sterile deionized water. The final $\mathrm{J} 2$ pellet was frozen and stored at $-80^{\circ} \mathrm{C}$.

Preinfective $\mathrm{J} 2$ from the HMB and Palm B2 populations reared on oilseed radish were collected over a period of 3 days to be used as inoculum for the second-host sequence. Each of the HMB and Palm B2 first-host sequence nematode populations from oilseed radish were reared on each of the four plants, resulting in the production of eight additional $H$. schachtii populations, referred to as the second-host sequence populations. The Palmetto population was not included because of insufficient amounts of inoculum. Seeds of the four host species were planted in $80 \mathrm{~g}$ of 60 -mesh silica sand in plastic vials (20 dram, 3.7 by $6.2 \mathrm{~cm}$; Baxter Diagnostics, Hayward, CA). Vials had a 3-mm hole covered by a $2.5-\mathrm{cm}$-diameter circular nylon mesh on the bottom to allow for drainage without the loss of sand. Vials were placed in a Conviron growth chamber (Conviron Co., Winnipeg, Canada), with four replicates of each population-host treatment arranged according to a completely randomized design, and maintained at $22^{\circ} \mathrm{C}$ night and $28^{\circ} \mathrm{C}$ day, $12-\mathrm{h}$ photoperiods with a relative humidity of 65 to $70 \%$ and light intensity of $190 \mu \mathrm{E}$. After germination, seedlings were thinned to one plant per vial and were watered daily with a nutrient solution
$(0.078 \% \mathrm{~N}, 0.072 \% \mathrm{P}, 0.152 \% \mathrm{~K}$, and micronutrients; Growmore Co., Gardena, CA). After the expansion of first true leaves, each host was inoculated with $500 \mathrm{~J} 2$ obtained from the first-host sequence populations. At 38 days after inoculation (approximately two generations [17]) two replicates of 50 cysts from the resultant eight second-host sequence populations were collected and stored as previously described.

DNA isolation from cysts. Total genomic DNA was isolated from frozen cysts by a modification of Sambrook et al. (15). Cysts in $1.5-\mathrm{ml}$ microcentrifuge tubes were ground in $200 \mu \mathrm{l}$ of extraction buffer (20 mM Tris, pH 8.0; $100 \mathrm{mM}$ EDTA; 0.5\% sodium dodecyl sulfate, and $60 \mu \mathrm{g}$ of Proteinase K) using a pellet pestle (Kontes Scientific Glassware and Instruments, Vineland, NJ) and brought to a final volume of $500 \mu$ l. Samples were incubated in a $55^{\circ} \mathrm{C}$ water bath for $3 \mathrm{~h}$ and then subjected to phenol-chloroformisoamyl alcohol extraction (24:25:1, pH 6.7; Fisher Biotech, Fairlawn, NJ). The DNA was ethanol-precipitated, dissolved in $50 \mu \mathrm{l}$ of TE buffer (10 mM Tris and $1 \mathrm{mM}$ EDTA, pH 8), left at $4^{\circ} \mathrm{C}$ for $2 \mathrm{~h}$ with agitation, and centrifuged at $8,160 \times \mathrm{g}$ for $2 \mathrm{~min}$, after which the supernatant was collected. Samples were passed through Sepharose columns (Sepharose CL-6B; Pharmacia Biotechnology, Inc., Piscataway, NJ) (15) prepared as follows: $2 \mathrm{ml}$ of sepharose was added to the column and centrifuged for $2 \mathrm{~min}$ at $250 \times \mathrm{g}$, the excess liquid was discarded, the DNA in TE buffer was loaded into the QS-GS microcolumn (Midwest Scientific, Valley Park, MO) and centrifuged for $5 \mathrm{~min}$ at $250 \times \mathrm{g}$, and the DNA solution was collected in a microcentrifuge tube at the bottom of the column. The DNA concentration was measured using a Hoefer DyNA Quant 200 fluorometer (Hoefer Scientific Instruments, San Francisco, CA) and was typically 6 to $16 \mathrm{ng} / \mu \mathrm{l}$ (300 to $800 \mathrm{ng}$ of DNA).

DNA isolation from J2. Total genomic DNA was isolated from frozen $\mathrm{J} 2$ by a modification of procedures of Sambrook et al. (15). Extraction buffer $(300 \mu \mathrm{l})$ was added to the frozen $\mathrm{J} 2$, followed by incubation at $50^{\circ} \mathrm{C}$ for $4 \mathrm{~h}$ with agitation and phenol-chloroform extraction. The DNA was ethanol-precipitated and resuspended in $10 \mu \mathrm{l}$ of TE buffer. The DNA concentration was typically 150 to $400 \mathrm{ng} / \mu \mathrm{l}$ (1.5 to $4 \mu \mathrm{g}$ of DNA).

RAPD analyses. The DNA preparations for both AFLP and RAPD analyses were derived from the same pots. All the AFLP and RAPD results referred to as duplicates were from different DNA preparations.

Reactions using DNA extracted from cysts were performed according to Caswell-Chen et al. (5) with slight modification. The RAPD reactions used the commercial decamer primers A-3, A-6, A-8, and A-9 (Operon Technologies, Inc., Alameda, CA) (5) that were prepared according to manufacturer's instructions. Approximately 10 to $20 \mathrm{ng}$ of DNA was amplified in $25-\mu \mathrm{l}$ reaction volumes containing PCR buffer $(10 \mathrm{mM}$ Tris- $\mathrm{HCl}, 50 \mathrm{mM} \mathrm{KCl}, 1.5 \mathrm{mM}$ $\mathrm{MgCl}_{2}$, and $0.001 \%$ (wt/vol) gelatin, $\mathrm{pH} 8.3$ ), $0.4 \mathrm{mM}$ deoxynucleoside triphosphates (dNTPs), 15 to $17 \mathrm{ng}$ of decamer primer; 10 to $20 \mathrm{ng}$ of DNA template, and $1.5 \mathrm{U}$ of Taq polymerase (AmpliTaq; Perkin-Elmer Corp., Emeryville, CA). The PCR amplification conditions were as previously described (5). Approximately $10 \mu \mathrm{l}$ of the PCR product was visualized on a $1.5 \%$ agarose gel in TBE buffer (100 mM Tris, $100 \mathrm{mM}$ boric acid, and $2 \mathrm{mM}$ EDTA) by ethidium bromide staining $(0.5 \mu \mathrm{g} / \mathrm{ml})$ and examined by UV transillumination. A molecular size marker was included (pGEM; Promega Corp., Madison, WI).

AFLP analysis. The AFLP procedure was a modification of Vos et al. (20), and DNA isolated from J2 was used for AFLP analyses. Approximately $250 \mathrm{ng}$ of genomic DNA was digested for at least $1 \mathrm{~h}$ at $37^{\circ} \mathrm{C}$ with $10 \mathrm{U}$ of EcoRI (Pharmacia Biotechnology, Inc.) and $5 \mathrm{U}$ of MseI (New England Biolabs, Inc., Beverly, MA). The 40- $\mu \mathrm{l}$ reaction volumes also included One-Phor-All Buffer (Pharmacia Biotechnology, Inc.), $6 \mathrm{mM}$ dithiothreitol, and $62.5 \mathrm{mM}$ bovine serum albumin. The templates for AFLPs were generated by ligating the MseI- and EcoRI-adapter sequences to the digested DNA as described 
by Vos et al. (20). After ligation, the reaction mixture was diluted threefold with sterile deionized water and stored at $-80^{\circ} \mathrm{C}$.

The first amplification employed EcoRI and MseI primers with no selective nucleotides (20). The reaction mixture for each $25-\mu \mathrm{l}$ sample included $2.5 \mu \mathrm{l}$ of the DNA template, $37.5 \mathrm{ng}$ of EcoRI primer, $37.5 \mathrm{ng}$ of $M s e$ I primer, $0.2 \mathrm{mM}$ dNTPs, PCR buffer, and $0.5 \mathrm{U}$ of Taq polymerase. The PCR was performed in an Ericomp thermal cycler (Ericomp Inc., San Diego, CA) for 30 cycles of $30 \mathrm{~s}$ at $94^{\circ} \mathrm{C}, 1 \mathrm{~min}$ at $56^{\circ} \mathrm{C}$, and $1 \mathrm{~min}$ at $72^{\circ} \mathrm{C}$.

For selective amplification of the secondary template, an EcoRI primer with one to three selective nucleotides at the $3^{\prime}$ end and a MseI primer with one to three selective nucleotides at the $3^{\prime}$ end were used. Four selective-primer pairs with the following selective sequences ( $5^{\prime}$ to $3^{\prime}$ ) were used: (i) EcoRI primer + CAG and MseI primer + G; (ii) EcoRI primer $+\mathrm{CG}$ and MseI primer + $\mathrm{CCA}$; (iii) EcoRI primer $+\mathrm{CG}$ and MseI primer $+\mathrm{AC}$; and (iv) EcoRI primer + CG and MseI primer + G.

The EcoRI primer was end-labeled with ${ }^{33} \mathrm{P}$, and $1 \mu \mathrm{l}$ containing $6.25 \mathrm{ng}$ of the primer per sample was added to $14 \mu \mathrm{l}$ of nonlabeled primer reaction mixture that contained $2 \mu$ of $10 \times$ PCR buffer, $23.75 \mathrm{ng}$ of EcoRI primer, $30 \mathrm{ng}$ of $M s e \mathrm{I}$ primer, $0.28 \mathrm{mM} \mathrm{dNTPs}$, and $0.4 \mathrm{U}$ of $T a q$ polymerase. Next, $5 \mu$ of the secondary template was added, bringing the total volume to $20 \mu \mathrm{l}$ for each sample. PCR was performed according to Vos et al. (20).

AFLP gel analysis. Following amplification, products were mixed with an equal volume of a $2 \times$ sequencing dye (20), denatured at $90^{\circ} \mathrm{C}$ for $5 \mathrm{~min}$, and then placed in ice. A total of $3 \mu \mathrm{l}$ of each sample was loaded on a $4.5 \%$ denaturing polyacrylamide gel cast in a NUGENeration Sequencing Electrophoresis System (Owl Scientific Plastics, Cambridge, MA). The running buffer was $1 \times$ TBE, and electrophoresis was performed at $80 \mathrm{~W}$ for $\approx 1.5 \mathrm{~h}$. The gel was removed from glass plates, dried at $80^{\circ} \mathrm{C}$ for $1.5 \mathrm{~h}$, and exposed to Kodak Scientific Imaging Film (Eastman Kodak Co., Rochester, NY) at room temperature for 60 to $72 \mathrm{~h}$.

\section{RESULTS}

RAPD analysis of host-induced population responses. After DNA from nine $H$. schachtii first-host sequence populations was isolated, PCR was performed with four RAPD primers. Primer A-3 yielded a low number of bands ranging in size from approximately 325 to 1,200 bp (Fig. 1). Other primers yielded similar but more

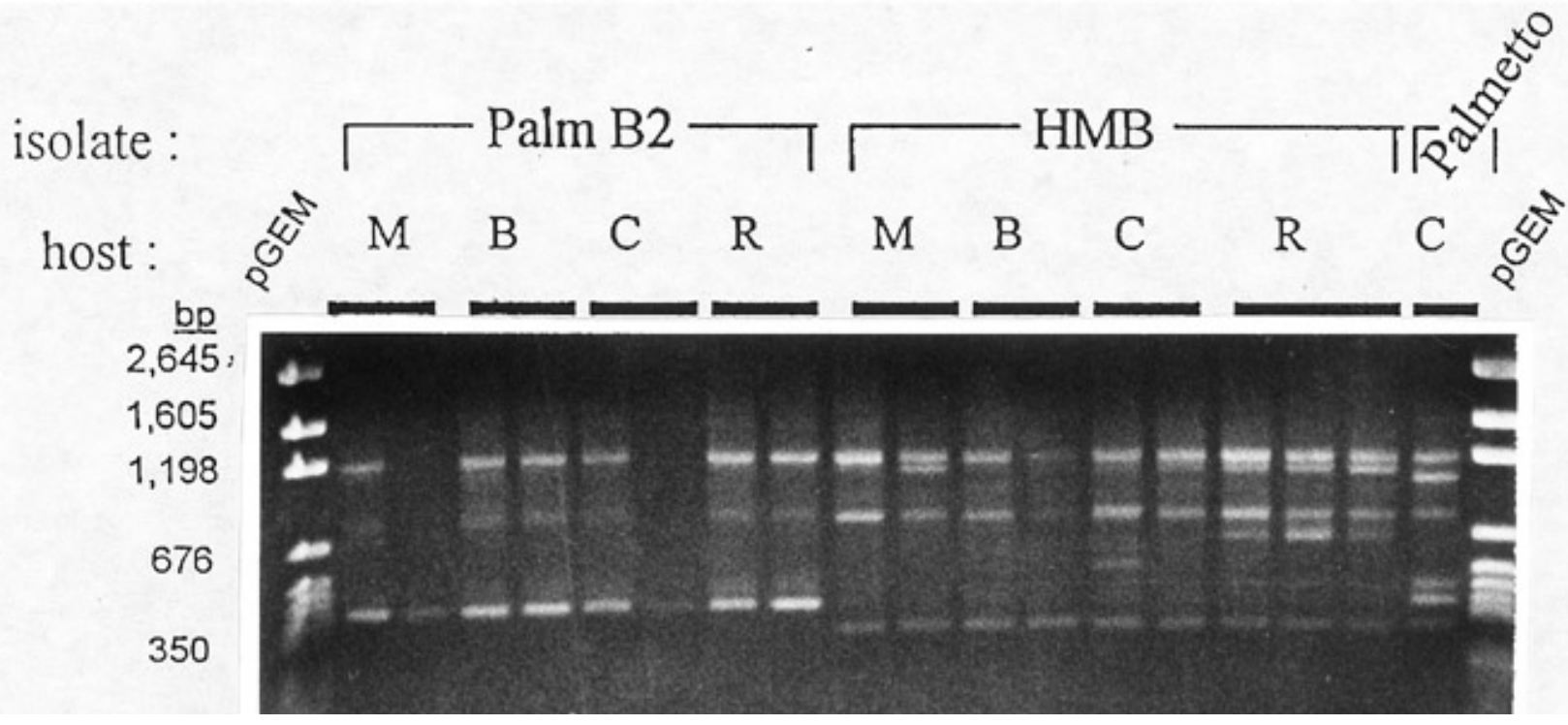

Fig. 1. Random amplified polymorphic DNA patterns generated with decamer primer A-3 (after first-host sequence). DNA was extracted from $\approx 50$ cysts of nine Heterodera schachtii populations originating from different geographic locations and reared on four host plants. $\mathrm{M}=$ white mustard, $\mathrm{B}=$ sugar beet, $\mathrm{C}=$ cabbage, and $\mathrm{R}=$ oilseed radish. Duplicate lanes were from different DNA preparations.

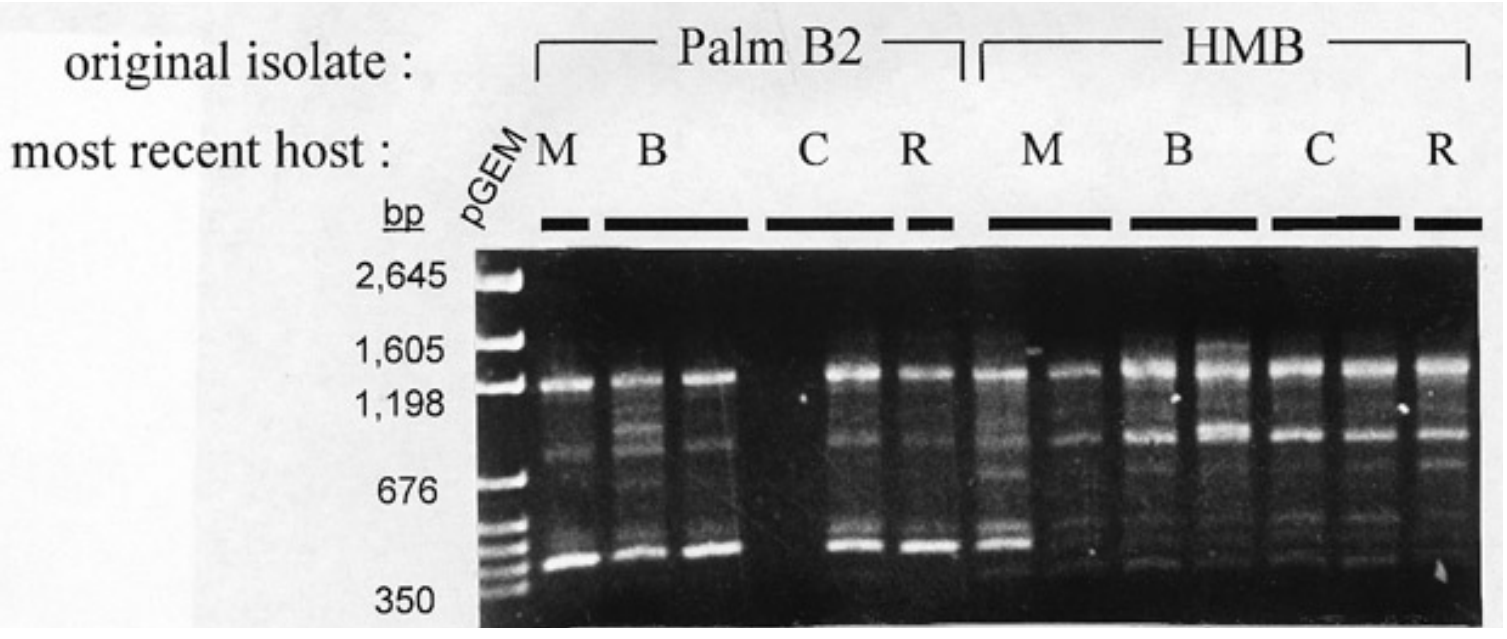

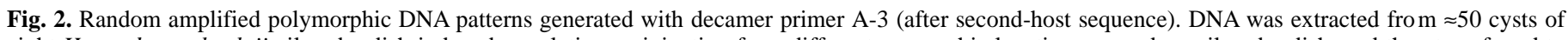

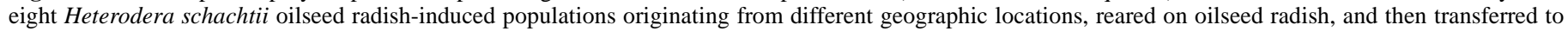
four host plants. $\mathrm{M}=$ white mustard, $\mathrm{B}=$ sugar beet, $\mathrm{C}=$ cabbage, and $\mathrm{R}=$ oilseed radish. Duplicate lanes were from different $\mathrm{DNA}$ preparations. 
complex patterns that were less easily interpreted. Thus, only primer A-3 is discussed here. Irrespective of the host, the three original isolates remained readily distinguishable with primer A-3 (Fig. 1). The smallest band visible from the Palm B2 populations was $396 \mathrm{bp}$, while the smallest HMB band was 325 bp. The Palmetto population had both the 325- and 396-bp bands, but was distinct from all populations of both of the other isolates with a third low-weight band and a 1,050-bp band. The HMB isolate reared on oilseed radish exhibited an additional 675-bp band that was not seen in any of the other HMB populations (Fig. 1). After HMB from oilseed radish was reared on each of the four original plants to yield the second-host sequence populations, the 675-bp band with primer A-3 was seen for all populations except one of the white mustard replicates (Fig. 2). However, the white mustard lane that lacks the band of interest is much paler than the other lanes, so it is possible that the 675-bp band was present but too pale to be seen. The first HMB white mustard lane (Fig. 1) appears to have a similar banding pattern to both the HMB and the Palm B2 populations hav- ing all of the bands typical of HMB, with the intensity of the 396-bp Palm B2 band.

AFLP analysis of host-induced population responses. The three $H$. schachtii isolates were readily distinguishable with AFLP primers (Fig. 3). Using selective-primer pair 2, Palm B2 and Palmetto appeared to be more similar to one another than either one of them was to HMB (Fig. 3). The Imperial Valley populations had multiple common bands that were distinct from the HMB populations (Fig. 3). After growth on oilseed radish, Imperial Valley populations had markers that were distinct from those populations on the other three hosts (Fig. 3). By using selective-primer pair 1, a marker was seen that distinguished the Palm B2 population on white mustard from the other Palm B2 populations (Fig. 4). Results from different DNA preparations were consistent across replicates (Figs. 3 and 4). No differences were observed among the $H$. schachtii populations using selective-primer pairs 3 and 4 (data not shown). All of the selective-primer pairs resulted in nematode AFLP

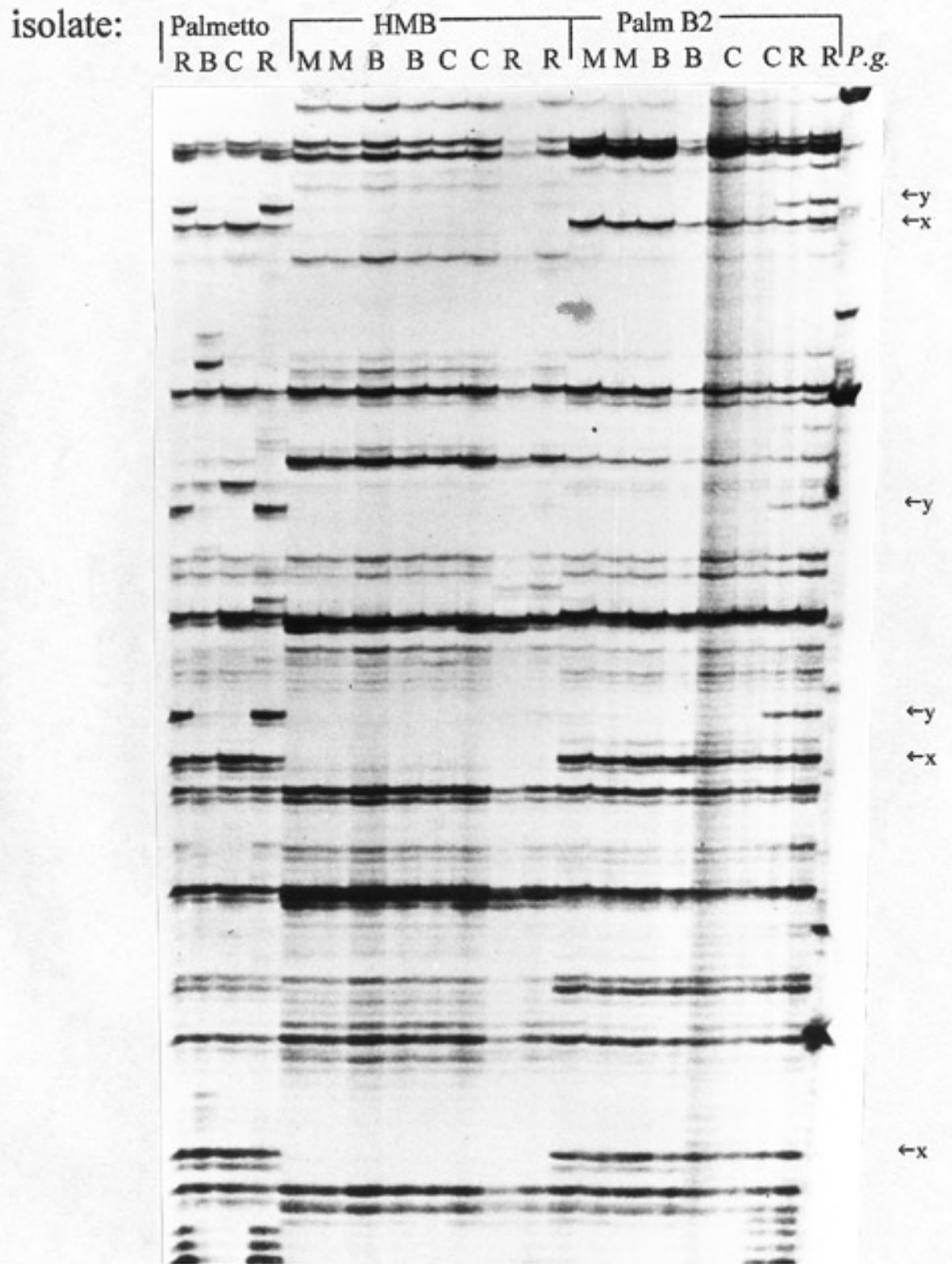

Fig. 3. Amplified fragment length polymorphism (AFLP) patterns generated with DNA from $\approx 2,000$ second-stage juveniles of 10 Heterodera schachtii populations originating from different geographic locations and reared on four hosts (first-host sequence). Primer pair was composed of selective bases: EcoRI primer + CG and MseI primer + CCA. Duplicate lanes were from different DNA preparations. $\mathrm{M}=$ white mustard, B = sugar beet, $\mathrm{C}=$ cabbage, and $\mathrm{R}=$ oilseed radish. P.g. = AFLP of DNA from the fungus Phaeoisariopsis griseola, $\mathrm{x}=$ distinct markers for Imperial Valley populations versus Half Moon Bay (HMB) populations, and $\mathrm{y}=$ distinct markers for Imperial Valley populations on oilseed radish. 
patterns that were different from the fungal control AFLP pattern (Figs. 3 and 4).

\section{DISCUSSION}

Biotic and abiotic factors in the environment may influence gene frequencies within any given nematode population in different ways (3). Individuals within a population can vary with respect to their host range not only in terms of their ability to penetrate, develop, and reproduce on a given host, but also with respect to their pathogenicity or aggressiveness on that host (2).

Using molecular markers, we demonstrated that genetic polymorphisms within a population are selected by different host plants. The polymorphisms depended on the genotype of the initial population and the host on which the nematodes had been reared. Phenotypic differences that correspond with genetically distinct geographic isolates of $H$. schachtii have also been identified after growth of these isolates on plants of different host quality (M. Kaplan and E. P. Caswell-Chen, unpublished data).

Differences among $H$. schachtii populations that originated from the HMB isolate demonstrated that selection, mutation, or genetic drift occurred. Because the initial inoculum included a large number of individuals, our observations probably were not the result of a founder effect. During the experiments, there was time for the nematode populations to undergo a maximum of four generations on each of the four plants. Since the results were consistent across replicates, genetic drift and mutation were not likely to have caused the observed variability. Thus, our results lead us to conclude that oilseed radish selected a subset of the original genotypic pool.

The absence of the 675-bp RAPD band in the HMB population on cabbage after the first-host sequence and the presence of the 675-bp RAPD band in the HMB population on cabbage after the second-host sequence are also suggestive of selection. The original isolates had been cultured on cabbage since 1991, so all of the

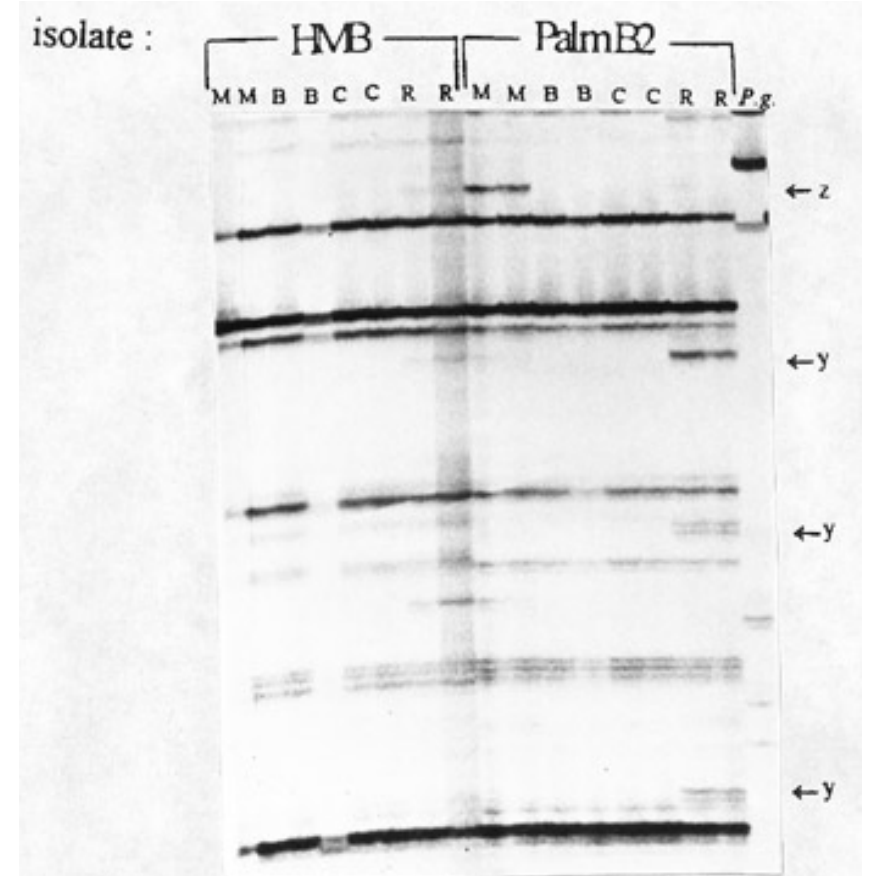

Fig. 4. Amplified fragment length polymorphism (AFLP) patterns generated with DNA from $\approx 2,000$ second-stage juveniles of eight Heterodera schachtii populations originating from different geographic locations and reared on four hosts (first-host sequence). Primer pair was composed of selective bases: EcoRI primer + CAG and MseI primer + G. Duplicate lanes were from different DNA preparations. $\mathrm{M}=$ white mustard, $\mathrm{B}=$ sugar beet, $\mathrm{C}=$ cabbage, and $\mathrm{R}=$ oilseed radish. P.g. = AFLP for DNA from the fungus Phaeoisariopsis griseola, $\mathrm{y}=$ distinct markers for Palm B2 populations on oilseed radish, and $\mathrm{Z}=$ distinct markers for Palm B2 populations on white mustard.
HMB genotypes are believed to have been present in the HMB cabbage population. However, because the 675-bp band was not seen in the HMB population on cabbage, it is possible that it was present at such a low frequency, relative to the other genotypes in the original isolate, that it was essentially displaced by the more frequent genotypes during amplification. The portion of the population carrying the allele associated with the 675-bp band was capable of surviving and reproducing on cabbage, because it was visible after amplification as long as it was present at a sufficiently high initial frequency. However, the band appears more intense from the cysts most recently on oilseed radish than from the other hosts. This may indicate that the oilseed radish selected primarily, but not exclusively, for a relatively rare genotype.

Results from AFLP analyses were in close agreement with the RAPD analyses, indicating the utility of both techniques for distinguishing populations. The Palm B2 and Palmetto isolates appeared more similar to one another than to the HMB isolate, in general agreement with the RAPD results reported by Caswell-Chen et al. (5) and the RAPD results observed for the first-host sequence. These results are supported by the geographic proximity and environmental similarity of sites of origin of the isolates and the possible history of $H$. schachtii introduction. As was seen with the RAPDs, populations produced on oilseed radish after cabbage had markers distinct from those populations from the other three hosts. Using AFLPs, we identified several distinct markers for an Imperial Valley population on oilseed radish and white mustard; using RAPDs, we identified distinct markers for the HMB population on oilseed radish.

The results emphasize the rapidity of host-induced selection on $H$. schachtii populations and the potential of molecular markers as tools for identifying and monitoring intraspecific $H$. schachtii genetic variability. Our results indicate that both AFLP and RAPD techniques are useful in this regard. The RAPD analyses can be conducted with relatively crude DNA obtained from $H$. schachtii cysts; however, AFLPs require clean DNA, such as that from juveniles, that can be cleaved to completion by restriction enzymes. Identifying the genetic variability and understanding nematode population responses to host plants ultimately will assist in assessing crop-mediated management programs and will potentially aid in identifying more stable resistance genes. Future research may identify genetic markers that are tightly linked to loci affecting pathogenicity and virulence. We have been able to identify reproducible molecular markers that distinguish host-selected populations after very few nematode generations using only a limited number of molecular primers. It is crucial to assess the long-term effects of host-induced selection pressure in the field to determine whether or not useful markers can be evaluated and employed on a wide scale for resistance management.

In conclusion, our results show that genotypic changes in nematode populations are selected by plants of differing host quality. Under controlled environmental conditions, different host plants altered the presence and frequency of certain alleles in $H$. schachtii populations. Both AFLPs and RAPDs revealed that oilseed radish, the poorest of the four host plants (i.e., supports the least amount of $H$. schachtii reproduction), resulted in the greatest number of changes in molecular markers. The genotypes represented in the host-induced populations were influenced by the genetic composition of the original nematode isolates. Thus, changes in population genotypes were the result of host selection, with oilseed radish having imposed the greatest selection pressure on $H$. schachtii. Genetically distinct $H$. schachtii isolates responded differently to the selection pressure exerted by a particular host.

\section{ACKNOWLEDGMENTS}

This research was supported by award 9603339 of the NRICGP/ USDA, Jastro-Shields Research Scholarship funds, and grants from the California Sugar Beet Growers Association. We thank P. van Zandvoort 
and F. Gommers for their advice concerning AFLPs; G. Caryl for her technical support; I. Kaloshian and B. Ferrie for helpful discussions; and L. Burton for assistance at the Controlled Environment Facility, University of California, Davis.

\section{LITERATURE CITED}

1. Anonymous. 1992. Biological Nematode Control. Saaten Union: Hanover. Gemeinschaft mit beschrankter Haftung.

2. Brown, J. K. M. 1996. The choice of molecular marker methods for population genetic studies of plant pathogens. New Phytol. 133:183-195.

3. Caswell, E. P., and Roberts, P. A. 1987. Nematode population genetics. Pages 390-397 in: Vistas on Nematology. J. A. Veech and D. W. Dickson, eds. Society of Nematologists, Inc., Hyattsville, MD.

4. Caswell, E. P., Thomason, I. J., and McKinney, H. E. 1985. Extraction of cysts and eggs of Heterodera schachtii from soil with an assessment of extraction efficiency. J. Nematol. 17:337-340.

5. Caswell-Chen, E. P., Williamson, V. M., and Wu, F. F. 1992. Identification of Heterodera cruciferae and $H$. schachtii and assessment of withinspecies genetic variation using random amplified polymorphic DNA. J. Nematol. 24:343-351.

6. Devos, K. M., and Gale, M. D. 1992. The use of random amplified polymorphic DNA markers in wheat. Theor. Appl. Genet. 84:567-572.

7. Folkertsma, R. T., Rouppe van der Voort, J. N. A. M., de Groot, K. E., van Zandvoort, P. M., Schots, A., Gommers, F. J., Helder, J., and Bakker, J. 1996. Gene pool similarities of potato cyst nematode populations assessed by AFLP analysis. Mol. Plant-Microbe Interact. 9:47-54.

8. Gardner, J., and Caswell-Chen, E. P. 1993. Penetration, development, and reproduction of Heterodera schachtii on Fagopyrum esculentum, Phacelia tanacetifolia, Raphanus sativus, Sinapis alba, and Brassica oleracea. J. Nematol. 25:695-702.

9. Griffin, G. D. 1981. Pathological differences in Heterodera schachtii populations. J. Nematol. 13:191-195.

10. Hartwig, E. E. 1981. Breeding productive soybean cultivars resistant to the soybean cyst nematode for the southern United States. Plant Dis. 65: 303-307.

11. McCann, J., Luedders, V. D., and Dropkin, V. H. 1982. Selection and reproduction of soybean cyst nematodes on resistant soybeans. Crop Sci. 22:78-80.

12. McKenry, M. V., and Roberts, P. A. 1985. Phytonematology Study Guide. Coop. Ext. Univ. Calif. DANR Publications, Oakland, CA.

13. Miller, L. 1986. Economic importance of cyst nematodes in North America. Pages 373-386 in: Cyst Nematodes. F. Lamberti and C. E. Taylor, eds. Plenum Press, New York.

14. Müller, J. 1992. Detection of pathotypes by assessing the virulence of Heterodera schachtii populations. Nematologica 38:50-64.

15. Sambrook, J., Fritsch, E. F., and Maniatis, T. 1989. Molecular Cloning: A Laboratory Manual. Cold Spring Harbor Laboratory Press, Cold Spring Harbor, NY.

16. Sidhu, G. S., and Webster, J. M. 1981. The genetics of plant-nematode parasitic systems. Bot. Rev. 47:387-419.

17. Steele, A. E. 1984. Nematode parasites of sugar beet. Pages 507-569 in: Plant and Insect Nematodes. W. R. Nickle, ed. Marcel Dekker, New York.

18. Steudel, V. W., Schlang, J., and Müller, J. 1989. Studies on the influence of catch crops on population dynamics of the sugar beet nematode (Heterodera schachtii Schmidt) in a sugar beet/cereal rotation. Nachrichtenbl. Dtsch. Pflanzenschutzdienst 41:199-203.

19. Townshend, J. L. 1963. A modification and evaluation of the apparatus for the Oostenbrink direct cottonwood filter extraction methods. Nematologica 9:106-110.

20. Vos, P., Hogers, R., Bleeker, M., Reijans, M., van de Lee, T., Hornes, M., Frijters, A., Pot, J., Peleman, J., Kuiper, M., and Zabeau, M. 1995. AFLP: A new technique for DNA fingerprinting. Nucleic Acids Res. 23: 4407-4414.

21. Williams, J. G. K., Kubelik, A. R., Livak, K. J., Rafalski, J. A., and Tingey, S. V. 1990. DNA polymorphisms amplified by arbitrary primers are useful as genetic markers. Nucleic Acids Res. 18:6531-6535.

22. Williams, J. G. K., Rafalski, J. A., and Tingey, S. V. 1991. Genetic analysis using RAPD markers. Methods Enzymol. 218:704. 